\section{anthropology} \& materialism

\section{Anthropology \& Materialism}

A Journal of Social Research

Special Issue | I | 2017

Discontinuous Infinities

\title{
The Task of the Philosopher
}

In Place of an Introduction

\section{Sebastian Truskolaski and Jan Sieber}

\section{(2) OpenEdition \\ Journals}

Electronic version

URL: http://journals.openedition.org/am/829

DOI: $10.4000 /$ am. 829

ISSN: 2364-0480

Publisher:

CETCOPRA, CRASSH - Center for Research in the Arts Social Sciences and Humanities, Fakultät Gestaltung - Universität der Künste Berlin

\section{Electronic reference}

Sebastian Truskolaski and Jan Sieber, «The Task of the Philosopher », Anthropology \& Materialism

[Online], Special Issue | I | 2017, Online since 07 March 2017, connection on 01 May 2019. URL : http:// journals.openedition.org/am/829

This text was automatically generated on 1 May 2019.

Tous droits réservés 


\title{
The Task of the Philosopher
}

\author{
In Place of an Introduction
}

\author{
Sebastian Truskolaski and Jan Sieber
}

Whenever the concept of a task appears in Benjamin's writings, readers can be sure that the author is referring to a particular task - a task which, we will find, determines his project in a fundamental way. The most prominent elucidation hereof can be found in “The Task of the Translator" (1921-23), Benjamin's famous preface to his translation of Baudelaire's Tableaux Parisiens. There he argues that "[i]t is the task of the translator to release in his own language that pure language which is exiled among alien tongues." ${ }^{1}$ As so often, Benjamin's enigmatic phrasing echoes his own earlier formulations: "the task of students", 2 in his early reflections on "The Life of Students" (1914-15); "the poetic task", ${ }^{3}$ in a piece from the same year, titled "Two Poems by Friedrich Hölderlin" (1914-15); "the task [...] of naming things", ${ }^{4}$ in his celebrated language-philosophical tract, "On Language as such and the Language of Man" (1916); "the task of the coming philosophy", ${ }^{5}$ in his essay "On the Program of the Coming Philosophy" (1918); "the task of the criticism of art", ${ }^{6}$ in his doctoral dissertation on The Concept of Art Criticism in German Romanticism (1919); and "the task of a critique of violence", 7 in his work on the "Critique of Violence" (1921). The concept of the task thus appears to be of central importance in Benjamin's early, theological-metaphysical writings - a set of works that is often seen as culminating with the publication of his ill-fated Habilitationsschrift, Origin of the German Mourning Play (1924-25/1928). ${ }^{8}$ Later on, the task comes to be replaced by other concepts and motifs, such as the destructive character's labour of demolition. ${ }^{9}$ It returns eventually, and with considerable prominence, in Benjamin's final work, the theses "On the Concept of History" (1940), which describe the "task to brush history against the grain", ${ }^{10}$ the "task to bring about a real state of emergency",11 and "the task of liberation in the name of generations of the downtrodden". ${ }^{12}$ Despite the varied contexts in which the concept of the task appears, and despite the numerous agents, acts, and themes to which it is linked, the general, conceptual function that Benjamin attributes to this figure is surprisingly consistent. It signals the demand for a new "language-philosophical foundation for the metaphysics of experience", as Werner Hamacher has put it;13 a philosophy of history that tacitly emerges from a confrontation between Kant and Neo-Kantianism, Classicism 
and Romanticism, a theologically inflected Anarchism and a radically recast vision of historical materialism.

2 It is for this reason that the concept of the task appears as an ideal starting point for the subsequent remarks, which aim to frame a collection of essays on Benjamin's philosophy a philosophy that is often hidden between the lines of his diverse, seemingly un- or even anti-systematic writings. As editors we take it that this publication marks a timely intervention into the current state of Benjamin-reception. After all, attempts to foreground Benjamin's philosophy have remained relatively few and far between, especially when compared with the steadily growing number of publications concerned to cast him in a variety of other roles: from Weimar broadcaster to "Marxist Rabbi", as Andrew Benjamin has put it. ${ }^{14}$ It is our conceit, however, that it is - above all - the philosophical character of Benjamin's work, which holds together its seemingly disparate strands. One way in which extant studies have sought to highlight this ostensible coherence has been by comparing different concepts from Benjamin's philosophical household on the basis of their general function, outlining a meta-theoretical schema for philosophical thought as it develops between his early writings and his later works. On this basis, it became possible to scrutinize the many references to the history of philosophy that run through Benjamin's work - from Plato to Leibniz, Kant, Nietzsche, Cohen and Husserl (to name only a few central players). However, whilst the immeasurable philological and intellectual-historical merit of such works is beyond dispute, the aim of this introduction (and the collection it serves to frame) is a different one: to begin to define what, for Benjamin, was not simply a task of philosophy, but the task of the philosopher.

3 To this end, it is worth highlighting that Benjamin makes several references to the "task of the philosopher" in the so-called "Epistemo-Critical Prologue" to his study on the Origin of the German Mourning Play. ${ }^{15}$ Insofar as the "Prologue" has long been viewed as a transitional point between the early theological-metaphysical writings, and the later, more self-consciously materialist works, Benjamin's formulation is consequential because it invites speculation as to the overall character of his philosophical programme. From this perspective, the following reflections - written in lieu of a conventional foreword focus largely on the "Prologue", beginning with the question what relation to philosophy is being proposed in this dense and cryptic text. More pointedly: if the "Prologue" sets out to define 'the task of the philosopher', does it - in fact - perform the task that it describes?

4 There are at least two ways of answering the question regarding the relation to philosophy laid out in the "Prologue" to Benjamin's study on the Baroque mourning play. On the one hand, it might be argued that the text has a merely propaedeutic function. From this viewpoint the "Prologue" does not perform 'the task of the philosopher', so much as it explains it from the outside by setting the epistemo-criticial stage for Benjamin's interpretation of the German Trauerspiel. 'The task of the philosopher' would thus appear as a theory of philosophical thought. However, such a reading surely misses Benjamin's extraordinary sensitivity to the ways in which traditional philosophical propaedeutics, such as Kant's, unduly restricted the parameters of experience - a problem with which the young Benjamin had extensively concerned himself. On the other hand, then, a more productive and interesting solution presents itself. On this reading, the "Prologue" does not merely present a theory of philosophical thought, but rather stages, performs and enacts 'the task of the philosopher'. From this viewpoint, the 
"Prologue" has to be read as positing the existence of an idea of philosophy, whose presentation - Darstellung ${ }^{16}$ - must become 'the task of the philosopher'. In this case, the presentation of philosophy's idea comes to determine its form and method, its relation to science and art, its account of the relation between knowledge and truth, being and thought, phenomena and ideas, and - significantly - its concept of history, all as it pertains to philosophy's own historical now.

In light of this short gloss, it remains to explore Benjamin's philosophical 'task' under five central aspects: i.) His account of the annihilation of the subject; ii.) His account of the task's two-fold character; iii.) His account of the role of language in the task's formulation; iv.) His account of the significance of origins and the world of phenomena; v.) And, finally, his account of the link between the theory of ideas and the figure of the monad.

6 i.) Who is 'the' philosopher? The idiom of a task might lead one to assume that there must be a subject of philosophical thought. However, as is well known, Benjamin - from his earliest writings - engaged in a fierce critique of the concept of a self-conscious, knowing subject. As he argues, the problem with such a conception of subjecthood arises from a perceived deficiency of Kantian philosophy, namely its limited concept of experience. ${ }^{17}$ In his essay "On the Program of the Coming Philosophy", for instance, Benjamin argues that Kant accounted for the timeless validity of knowledge, but not for the certainty of a singularly temporal experience - an experience that encompasses what, for Kant himself, was nothing less than the Enlightenment itself. Instead, Benjamin charges, Kant uncritically adopted an older view, which associates experience with pure or empirical consciousness, thus putting it in the service of mere knowledge. The task of the coming philosophy, therefore, "is, according to the typology of Kantian thought, to undertake the epistemological foundation of a higher concept of experience" 18 - an experience which, in turn, is the condition for what the "Prologue" describes as "truth". ${ }^{19}$ The formulation of such a higher concept of experience depends on the revision of the Kantian concept of knowledge - as distinct from a re-valorised conception of truth - and the annihilation of its metaphysical elements. The most important of these elements are "first, Kant's conception of knowledge as a relation between some sort of subjects and objects or subject and object [...]; and, second, the relation of knowledge and experience to human empirical consciousness". ${ }^{20}$ For Benjamin the concept of the subject as cognising consciousness, in opposition to an object of knowledge - a notion formed in analogy to empirical consciousness - is the mythological substrate of Kantian and pre-Kantian epistemology. This "subject nature" ${ }^{21}$ has to be annihilated by philosophy in order to arrive at a de-subjectified concept of a pure epistemological (transcendental) consciousness ${ }^{22}$; in his earlier essay, "On Language as Such and on the Language of Man", Benjamin assigns this role to language, a point to which we will return in due course. Without presuming to adequately summarise this point here, it suffices to note that Benjamin's critique of Kant questions the traditional opposition between subject and object, and hence the subject's claim to knowledge and consciousness, as well as its intentionality, i.e. its possessive character. Benjamin's subject, if it were possible to speak of one, would be a voided subject, dispossessed, stripped of the a priori conditions of experience assigned to it by Kant. It would be a decentralised subject: the effect of an experience, rather than the condition of its possibility. It would be an operation in the weakest sense, albeit one with profound consequences, insofar as it would become the bearer of a truth that it does not possess, a truth that it does not know. 
7 Nevertheless, the question remains: who is the philosopher whose task Benjamin describes? This philosopher, as we have seen, cannot assume a position outside of history, from which she could give an objective account of the supra-temporal legitimacy of some self-same subject's thoughts or actions. On the contrary, the philosopher is subjected to historical experience, an experience whose truth it is her task to present. Accordingly, Benjamin's philosopher is one who is in search of truth, a truth that does not belong to any subject or any object, but rather resides in a constellation of being whose legibility depends on the 'now' of a temporal, historical experience. ${ }^{23}$ To bring forth this truth is a central facet of 'the task of the philosopher'.

8 ii.) Having thus given some indication as to how one might figure the ostensible subject of Benjamin's task, let us explore the task's double character. If, as Benjamin suggests in the "Prologue", truth resides in a constellation of being, rather than, say, in the seamless correspondence of subject and predicate, then it follows that this truth is, above all, relational. If we concede this point, then the philosopher's task appears as a constructive one: to establish this relation between the world of ideas and the empirical world. The 'task of the philosopher' would thus have to be twofold: on the one hand, to present darstellen - the world of ideas; on the other hand, to engage with the empirical world in such a way that it would enter and dissolve into the former - a process that Benjamin describes as Rettung (rescue). It is worth emphasising that the double nature of Benjamin's task lets the philosopher occupy

an elevated position between that of the scientist and the artist. The latter sketches a restricted image of the world of ideas, which, because it is conceived as a metaphor, is at all times definitive. The scientist arranges the world with a view to its dispersal in the realm of ideas, by dividing it from within into concepts. He shares the philosopher's interest in the elimination of the merely empirical; while the artist shares with the philosopher the task of presentation. ${ }^{24}$

By positioning the philosopher between the scientist and the artist, this passage recalls the entire history of rivalries, alliances, and struggles between philosophy, science, and art. In Benjamin's account of their relation, it is not philosophy's task to legitimate the objectivity of scientific knowledge, as Kant would have had it; nor is art the organon of philosophy, as it had been for the Jena Romantics; nor, finally, is philosophy the sublation of art as a lower form of spirit, as Hegel had argued. For Benjamin, philosophy does not relate to science and art as distinct objects of philosophical inquiry. Philosophy itself has both a scientific and an aesthetic dimension. 'The scientist' and 'the artist' are not mere metaphors; rather, they stand in for two correlative methodological aspects of 'the task of the philosopher': to engage the empirical world in the manner of the scientist, and - at the same time - to present the world of ideas in the manner of the artist.

The scientific dimension of this task concerns the compilation of the empirical world by means of the concept. As Benjamin argues,

Phenomena do not [...] enter into the realm of ideas whole, in their crude empirical state, adulterated by appearances, but only in their basic elements, redeemed. They are divested of their false unity so that, thus divided, they might partake of the genuine unity of truth. In this their division, phenomena are subordinate to concepts, for it is the latter which effect the resolution of objects into their constituent elements. ${ }^{25}$

11 Contrary to Kant's epistemology, the concept's function is not to establish logical unity. Truth, for Benjamin, does not reside in a systematically completed, scientific knowledge of the empirical world. Rather, such knowledge is portrayed as an illusion common to 
many modern scientific theories, which attempt to unify the field of scientific disciplines. Instead, Benjamin suggests, the irreconcilability of disciplines in fact resembles the "discontinuous structure of the world of ideas" ${ }^{26}$ Such irreconcilability could help in the presentation of ideas, if it were not for science's hubristic desire to grasp truth as an encyclopaedic accumulation of data points. In opposition to the scientific demand for systematic coherence, the function of the concept in Benjamin's outline of the philosopher's task is to divide the empirical world - to dissolve it into its elements. Only in its dividing function does the concept take on the mediating role through which phenomena partake in the existence of ideas. Accordingly, Benjamin writes:

As the salvation of phenomena by means of ideas takes place, so too does the presentation of ideas through the medium of empirical reality. For ideas are not presented in themselves, but solely and exclusively in an arrangement of concrete elements in the concept: as the configuration of these elements. ${ }^{27}$

These elements manifest themselves most clearly in extremes, and, therefore, the concept takes the extreme as its starting point for a more thorough penetration of the empirical. Nevertheless, such a division of the empirical world in the concept is never merely a destructive act. Rather, it is a gathering of elements that is directed towards presenting the idea and, hence, truth. From the standpoint of science, 'the task of the philosopher', then, lies in dividing and dispersing the empirical world in the concept as the condition of the possibility for its correlation with the world of ideas. The philosopher, by means of the concept, destructs the false unity of the world, thus liberating it from its imaginary totality. Accordingly, the world - dissolved into its elements - may partake in the presentation of ideas.

Such a presentation of ideas constitutes the other side of philosopher's task, namely the side that it shares with art. The question of presentation, here, is itself twofold: on the one hand, it concerns the form of presentation; on the other hand, it concerns that which is to be presented. The problem of form is never resolved once and for all; time and again it must be at the heart of the philosopher's task. By the same token, philosophical form can neither be mathematically constructed, nor can it concern didactic intentions. It is neither identical with the classical view of philosophical systems, nor with the idea of an instructive guide for understanding. Philosophy can neither anticipate its form, nor its means of communicating with others. In other words, presentation is not merely a means for the purposes of systematic, comprehensible exposition. Accordingly, Benjamin suggests, the question of presentation is best addressed when philosophy assumes the form a treatise. As he writes, the method of the treatise

is essentially presentation. Method is a digression. Presentation as such is the methodological nature of the treatise. The absence of an uninterrupted purposeful structure is its primary characteristic. Tirelessly the process of thinking makes new beginnings, returning in a roundabout way to its original object. This continual pausing for breath is the mode most proper to the process of contemplation. For by pursuing different levels of meaning in its examination of one single object it receives both the incentive to begin again and the justification for its irregular rhythm. ${ }^{28}$

Discontinuity and repetition are the two main characteristics of philosophical form. Thought assumes these traits if it truly immerses itself in its subject matter. Such philosophical writing has a particular prosaic rhythm. At times it comes to a standstill, begins anew, or jumps between disparate elements. 
15 While this aspect of form correlates with the divisive task of the scientist, the concern with that which is to be presented puts philosophy into the orbit of the artist. Like the artist, the philosopher envisions an image of the world of ideas - an image which 'is at all times definitive'. This philosophical image does not intend validity beyond its own time, but rather yields temporal, historical truth. It presents the world of ideas in the medium of the empirical. However, this does not mean that the empirical world, divided into its elements by the concept, is mere material for the philosophical image. What is at stake in the task of presentation is, firstly, Benjamin's differentiation between knowledge and truth, and, secondly, his peculiar view of the relation between ideas and phenomena. With regards to the former, knowledge and truth differ in their respective relations to their objects. Knowledge treats its objects as property, as Benjamin puts it.

Knowledge is possession. Its very object is determined by the fact that it must be taken possession of - even if in a transcendental sense - in the consciousness. The quality of possession remains. For the thing possessed, presentation is secondary; it does not have prior existence as something presenting itself. ${ }^{29}$

16 Once again, Benjamin formulates his critique of scientific knowledge in opposition to Kantian epistemology. Producing knowledge in a Kantian sense is, for Benjamin, a form of appropriation that captures its object as property. Whatever can be registered and made coherent according to the a priori categories of understanding, and the corresponding forms of intuition, is seized by consciousness. 'Method', then, is a mere means of appropriation. Objects are never taken on their own terms; they are subordinated to the rule of reason. For truth, however, presentation is a primary concern. In contrast to knowledge, truth is self-presentation; not the product of a logical appropriation of an external object, but immanent to the method of the object's elaboration. As Benjamin states with reference to Plato's theory of ideas: "[ $t]$ he object of knowledge is not identical with the truth" ${ }^{30}$ With regards to the question of unity, this pertains to both knowledge and truth, albeit in very different ways. The unity of knowledge means the conceptual coherence of individual insights constituted through the application of its formal method. Put differently, the unity of knowledge is not determined by the individual phenomena that it appropriates, but by the method of their appropriation in consciousness. By contrast, the unity of truth is derived from being. It is unmediated/ immediate: a unity in being, not a unity in the concept. As such, it is not a unity of being, which has been forgotten in the course of history, or hidden behind the false appearance of an alienated world, as it had been for Heidegger. ${ }^{31}$

The philosopher's double task, then, is to dissolve the empirical into its elements, albeit not in order to unveil or reveal some underlying reality. Truth's unity is in being. It means a unity integral to truth, which cannot be turned into an external object for thought. As Benjamin highlights, the unity of truth "is not open to question". ${ }^{32}$ For if truth had an answer to the question of its own unity, then this answer would already imply a unity of a different sort - a unity other than the one contained in the answer given. Every such answer would therefore necessarily lead to the repetition of the question that produced it. Truth, in this regard, is unity as being, as Benjamin goes on to suggest. However, as remains to be seen, this being is not essential; rather, it is historical.

The second aspect of the 'task', noted above, is to do with Benjamin's characterisation of the being of ideas. As in the case of truth, ideas are said to exist; however, unlike truth, they are given. "Ideas are pre-existent", ${ }^{33}$ Benjamin argues, they are ein Vorgegebenes. Herein resides Benjamin's peculiar Platonism, which he deploys to correct certain 
perceived failings of Kant's epistemology. However, Benjamin's ontology of ideas is eccentrically coloured by his own theologico-metaphysical philosophy of language, as well as motifs borrowed from Leibniz's Monadology. (A brief discussion of Benjamin's relation to Leibniz will follow in due course.) For the time being, it suffices to note the following: if truth, as Plato argues in the Symposium, guarantees the being of beauty, i.e. if truth is the content of beauty, then, Benjamin argues, the same holds true for the being of ideas. Truth neither discloses a content, nor does it expose a secret. Just as truth is inextricably linked to beauty qua semblance, so it is immanent to the presentation of ideas - and here Benjamin departs from Plato - that it appears as a configuration of conceptually mediated, phenomenal elements. But how do phenomena and ideas relate to each other in the first place? Phenomena are not, as Benjamin stresses, contained in ideas. Ideas are rather their "objective interpretation". ${ }^{34}$ This, however, does not mean that they act as their concepts or laws. Ideas neither serve the knowledge of phenomena, nor do phenomena simply attest to the existence of the ideas. Phenomena and ideas belong to fundamentally different realms. Just as phenomena are not contained in ideas, ideas are not given in the world of phenomena. Therefore they cannot be made into the objects of intellectual vision, intellectual intuition. Ideas elude any kind of intentional grasp. Thus Benjamin argues, "[t]ruth does not enter into relationships, particularly intentional ones. ${ }^{35}$ Rather than entering into a relation - e.g. when a subject intends to tell the truth - truth is the relation between phenomena and ideas. If ideas are 'objective interpretations', insofar as they put phenomena (or rather their elements) in relation to each other, i.e. if they construct constellations, then truth means a particular correlation between the empirical world, and the world of ideas - a correlation through which the empirical divests itself of its mere phenomenality, thus exposing an image of the idea. If Benjamin's view suggests a kind of correlationism, then this does not mean a coincidence of thought and objects. (After all, as we have seen, Benjamin blurs the boundaries between conventional accounts of subject-object dialectics.) The inessential correlation between phenomena and ideas appears in what Benjamin describes elsewhere as a 'now'. "Truth resides in the "now of knowability." ${ }^{36}$ This correlation of phenomena and ideas in a 'now', in turn, is mediated through language. Language and history thus appear as the media of philosophical thought.

19 In sum: it is the double 'task of the philosopher' to engage the empirical world in the manner of the scientist, and - at the same time - to present the world of ideas in the manner of the artist. The philosopher destructs the false unity of the empirical world and dissolves it into its elements by means of the concept, so that an image of the world of ideas may appear as a constellation of these elements. The possibility of such an interpretation of the world in the order of ideas, however, is grounded in language and history.

iii.) Benjamin's reflections on the correlation between phenomena and ideas stem from another important aspect of his philosophy, namely: his philosophy of language. Philosophical thought is, for Benjamin, fundamentally dependent on language. Accordingly he argues that

It is the task of the philosopher to restore, by presentation, the primacy of the symbolic character of the word, in which the idea is given self-consciousness, and that is the opposite of all outwardly-directed communication. Since philosophy may not presume to speak in the tones of revelation, this can only be achieved by recalling in memory the primordial form of perception. ${ }^{37}$ 
21 "The Task of the Translator", "On Language as Such and on the Language of Man", as well as several posthumously published fragments on perception. The task of presenting ideas is thus framed in terms of his philosophy of language: the restoration of 'the symbolic character of the word', through 'presentation' - Darstellung - elevates the idea to 'selfconsciousness' in a manner that is diametrically opposed to 'all outwardly-directed communication' - an undertaking that, in turn, relates to 'memory' and, moreover, to a 'primordial form of perception', albeit in ways that Benjamin does not fully elaborate here. ${ }^{38}$

It is worth emphasising the following: since his earliest writings, Benjamin sharply criticised an understanding of language in terms of 'outwardly-directed' communication. What is more, he equates the dictate of communication with a "bourgeois" paradigm that tends to instrumentalise language as a means to an end. ${ }^{39}$ By contrast, he suggests, language 'communicates' nothing but itself: "all language communicates itself in itself", not through itself; "it is in the purest sense the "medium' of communication." 40 At the same time, though, Benjamin distances himself from an esoteric view of language as an end in itself, by criticising an unspecified "mystical theory", according to which "the word is simply the essence of the thing." ${ }^{41}$ Along these axes, Benjamin sketches a theory of "pure language", set against the backdrop of the biblical story of genesis. ${ }^{42}$ To this effect, in his 1916 essay "On Language as Such and on the Language of Man", he portrays Adam as the first philosopher - the recipient of the creative "gift of language", ${ }^{43}$ which names creation into being. After the expulsion from Paradise, however, the creative power of Adamitic language is compromised. This is why the ideational dimension of language remains inaccessible, and 'philosophy may not presume to speak in tones of revelation'. Echoing Johann Georg Hamann's account of creation as a trace of God's divine word, Benjamin describes a mute language of nature, which demands 'translation': “the translation of the language of things into that of man". ${ }^{44}$ Such a translation, however, does not mean the mere transposition of one post-lapsarian tongue into another, as Benjamin elaborates in "The Task of the Translator"; nor does it mean a direct articulation of the word's 'symbolic character', as though it simply spoke through things themselves. The question thus arises as to how Benjamin proposes to relate to the symbolic character of the word', the realm of ideas, from this Babel-esque standpoint?

In terms of the "Prologue" one might argue as follows: if, in his 1916 essay, Benjamin portrays Adam rather than, say, Socrates, as the 'first' philosopher, because Adam receives the 'gift of language' from God; if, in turn, he argues that a mute language speaks through nature as the residue of God's creative word, and that this language - for its part - demands 'translation', albeit in a highly qualified sense, then the relation between language, the 'task' of presenting ideas, and an expanded concept of experience begins to come into focus. As Samuel Weber observes, “'[t]he task of philosophy' - since it cannot claim to reveal directly - consists in a certain kind of originary listening [...] that in turn entails remembrance. Through such remembering", Weber continues, "words are 'once again' given the ability to 'reassert their rights to name.' This is why", he argues, "neologisms - which also entail a certain naming - are to be avoided: for by introducing new words, they ignore the historical memory of language." ${ }^{45}$ Put another way, "it is the task of the philosopher to restore [...] the primacy of the symbolic character of the word' qua name, because only in the name is the idea raised to the level of 'self-consciousness' through the process of presentation. However, since, following the expulsion from 
Paradise, 'philosophy may not presume to speak in the tones of revelation', this can only be achieved negatively: by circumscribing a 'primordial form of perception', which once partook in the realm of ideas. Benjamin, in other words, does not simply purport to name ideas into being; rather, he outlines a language-philosophical model for constructing constellations of objects through which ideas may yet be experienced at the level of language. For Benjamin, then, language serves as the privileged model of experience because it disrupts the tidy distinctions of the Kantian system, including those that differentiate between 'subjects' and 'objects' of sensation. "Language", in other words, "serves as a medium of experience", the quasi-transcendental mediator between phenomena and ideas, which 'binds the ostensible 'subject' and 'object' in a more profound [...] relationship of underlying kinship." ${ }^{46}$

iv.) If language is the mediating instance between the world of ideas and the world of phenomena, then history is the site upon which this mediation manifests itself as origin. As is well known, Benjamin's concept of origin rejects any facile historicism, which conceives of history as a linear progression through time. Writing history, on this model, amounts to nothing more than the projection of distinctions and similarities between historical 'facts' into a pseudo-logical continuum. True historiography, for Benjamin, begins where the deductive method is abandoned and thought becomes absorbed in the singular phenomenon wherein it unfolds its truth-content. The same holds true for 'the task of the philosopher'. "The world of philosophical thought does not [...] evolve out of the continuum of conceptual deductions, but in a description of the world of ideas. To execute this description it is necessary to treat every idea as an original one." ${ }^{47}$ It's the task of philosophical contemplation to immerse itself in the empirical so as to rediscover it as the origin of the idea. Hence the concept of origin is, as Benjamin stresses, a historical category. It does not, however, designate the origin of a development. 'Origin' does not describe the first moment from which something takes its course. Accordingly, discovering an origin in history does not mean tracing a historical development backwards to where it is supposed to have begun. Rather, origin is where the historical continuum is interrupted. It is in the moment of a 'now', which is not logically deducible from historical facts, but rather changes its own past and subsequent history (Vor- und Nachgeschichte). As the twofold nature of 'the task of the philosopher' suggests, things only reveal themselves as origins under a dual kind of scrutiny. To present an idea requires the immersion into the singular. At the same time as the philosopher-quascientist destructs the false unity of the empirical world, and dissolves it into its elements by means of the concept, she destructs the false continuum of history and immerses herself in the singular fact. Accordingly, Benjamin writes:

Indeed this is where the task of the investigator begins, for he cannot regard such a fact as certain until its innermost structure appears to be so essential as to reveal it as an origin. The authentic - the hallmark of origin in phenomena - is the object of discovery, a discovery which is connected in a unique way with the process of recognition. ${ }^{48}$

The authenticity of historical facts, once more, does not consist in their logical connection. Rather, it derives from their innermost structure. Something appears as authentic inasmuch as it is governed by a dialectics of uniqueness and repetition. Origin is where a unique singularity escapes the historical continuum and reveals itself as the site of remembrance of the idea. is discontinuous. But it is not the universal, the idea, that gathers and sublates the 
discontinuous elements of history. On the contrary, only in the discontinuities that appear in the ideological unity of historical progression the idea presents itself. Therefore, philosophical history has to become a "science of the origin" ${ }^{49}$ which reveals the configuration of the idea in the discontinuous, the singular, the extreme. It is 'the task of the philosopher', as a historian of origins, to blast open the false continuum of history in order to rediscover the idea in the singular occurrence.

v.) Finally, in the latter part of the 'Prologue', Benjamin likens ideas to monads:

And so the real world could well constitute a task, in the sense that it would be a question of penetrating so deeply into everything real as to reveal thereby an objective interpretation of the world. In the light of such a task of penetration it is not surprising that the philosopher of the Monadology was also the founder of infinitesimal calculus. The idea is a monad - that means briefly: every idea contains the image of the world. The purpose of the presentation of the idea is nothing less than an abbreviated outline of this image of the world..$^{50}$

Benjamin's formulation is striking because it gives some important clues as to the provenance of his theory of ideas. Accordingly, it is worth emphasising that, in addition to the broadly Platonic issues debated in the "Prologue", Benjamin's description of the world as a 'task', and his references to both the Monadology and to infinitesimal calculus, situates him squarely in the midst of early $20^{\text {th }}$-century Leibniz reception - particularly as advanced by Hermann Cohen, Heinz Heimsoeth, and other figures from the Marburg School of Neo-Kantianism. ${ }^{51}$ In this regard, Benjamin's suggestion that the 'task' of 'penetrating so deeply into everything real as to reveal thereby an objective interpretation of the world' gives cause for pause. What is meant by objectivity in the context of a discussion of ideas, how does interpretative depth ensure such objectivity, and how does this relate to Leibniz?

29 The former question concerns Benjamin's attempt, in the "Prologue", to elaborate an ontology of ideas, that is, to ascribe to ideas a particular mode of being. As we have alluded to, this follows from his essay on "The Program of the Coming Philosophy", which sought to collapse the distinction between categories and ideas in order to extend the purportedly limited Kantian concept of experience to infinity. As we have seen, the unconditioned objects of ideas were thus to become possible objects of experience, at least indirectly so; but to forge such access to the world of ideas, and hence to truth, Benjamin has to elaborate on the mode of their existence - their 'objectivity'. Nevertheless, insofar as Benjamin - like Kant, but unlike the Jena Romantics - denies that there can be any intellectual intuition of the unconditioned content of ideas, this relation must be mediated in some sense through knowledge, i.e. through the very relation of possession that obtains in conventional subject-object dialectics, and which Benjamin so vehemently criticised. But how is one to conceive of an 'objective' relation to the unconditioned from the standpoint of the post-lapsarian world of the Baroque mourning play? In other words, how is one to conceive of the infinite from the standpoint of profane finitude? Or, put another way, how is one to conceive of a new form of totality that is not merely the sum of truncated singularities which have been more or less violently subsumed under larger conceptual headings?

It has already been suggested that the "Prologue" articulates two possible models for thinking this relation: one in terms of the dual operation of construction and interpretation (ideas are expressed through configurations of objects, which are raised to the level of experience through a process of interpretation, so that their elements are 'rescued', albeit in slightly mysterious ways); the other in terms of language (the paradoxical 
remembrance of a condition in which the ideational content of the word may yet be raised to the level of experience, although - again - in highly qualified ways). In a sense, then, the allusion to Leibniz can be seen to bridge these two 'models', insofar as Benjamin appears to view the monad as expressing an "immanent infinity". ${ }^{22}$ As Paula Schwebel argues, Benjamin reads Leibniz's contraction of infinity within finite beings as the consequence of a historical tendency, which he places under the heading of secularisation. Accordingly, the monad is supposed to express "an unfulfilled yearning for transcendence" in a fallen world, which is "forcibly redirected toward contingent nature. ${ }^{53}$ Infinity thus endures in the world through what Schwebel describes as Benjamin's "inverted metaphysics". ${ }^{54}$ In spite of the fact that "reason is denied access to the transcendence of the heavens", as Schwebel puts it, "in its pursuit of a fundamental grounding for contingent experience, thinking is drawn into an abyss of infinite analysis". ${ }^{55}$ This translates into the terms of our exposition as follows: for Benjamin the unity of an individual constellation, which is constructed through a process of interpretation, mirrors the unity of an idea, which is - in turn - an abbreviated expression of infinity 'within finite beings'. This is all the more striking since, as Schwebel suggests, Benjamin maps Leibniz's foremost mathematical innovation infinitesimal calculus - onto his account of the secularisation of history in the period following the 30 Years War. As she argues, Benjamin seeks to explain this development in terms of a "transformation of the meaning of creation, from a temporal stage on the way to salvation, to the immanent totality of what is." ${ }^{156}$ In this respect, Benjamin views the breakthrough of infinitesimal calculus as residing "in its transformation of infinity, from endless succession (a temporal notion) to an infinity of detail within (spatial) presence." 57 This is to say, by establishing a connection between the 'task' of presenting ideas in the guise of monads, on the one hand, and reading their abridged infinities in terms of a historical shift apparently facilitated by Leibnizian calculus, on the other, Benjamin is able to articulate one of the his central philosophical concerns: that history, far from being a mere aggregate of infinitely proliferating points, is 'an infinity of detail within (spatial) presence' - an infinity that demands a labour of interpretation to actualise its hidden correspondences in the eruptive 'now' articulated in his mature writings.

31 We have seen, then, some aspects of how Benjamin proposes to raise ideas (not least, the idea of history) to the level of experience through the philosophical task of presentation. By way of summarising the above, let us return to the general question posed at the outset: how are we to understand the 'task of the philosopher' as it appears in the "Epistemo-Critical Prologue" to Benjamin's study on the Origin of the German Mourning Play - the pivotal point between his early writings, and his later works? If, as has been suggested, Benjamin's "Prologue" seeks to perform the task of presenting the idea of philosophy, then this task must be read as an attempt to rescue philosophical thought under the historical conditions of modernity; to rescue it from the hubris of a selftransparent subject, the impoverishment of experience, the degradation of language to a mere instrument of communication, the reduction of truth to a system of knowledge and knowledge to a matter of possession, the abolition of history as a disposable accumulation of historical data points, and the distortion of the world through its subsumption under the value-form. Under these conditions, a systematic idea of philosophy (with strong, stable concepts of subject and object, reason, totality, and so on) can no longer be uncritically affirmed. Philosophy has to take upon itself the task to disempower the selftransparent subject, to wrest truth from knowledge, to discover the non-instrumental, non-signifying dimension of language, and to introduce breaks and fissures into the 
seemingly continuous connectedness of the world, and of history. Moreover, in order to perform this task, it must renounce all aspirations to systematic completeness, and take on the form of a treatise (Traktat) - an essayistic form that yields truth by destroying the false unity of the empirical world, and by presenting the idea within a constellation of profane elements. If philosophical thought is to be rescued, it has to perform a paradoxical task - a paradox that is captured by the double meaning of the German word Aufgabe, which, as Paul De Man has pointed out, means both 'task' and 'abandonment' or 'giving up'.58 Accordingly, we might say - following Benjamin - that 'the task of philosophy' is (self-)abandonment: die Aufgabe der Philosophie ist es sich aufzugeben. Benjamin's "Prologue" thus performs the task of presenting the idea of philosophy as the paradoxical task of the philosopher. Philosophy thus rescues philosophical thought, albeit in a different form, namely as Critical Theory.

With our special edition of Anthropology \& Materialism we want to contribute to the ongoing efforts to read Benjamin's Critical Theory philosophically. This does not mean retreating behind Benjamin's 'rescue' of philosophy by simply inscribing him into the history of ideas. On the contrary! We are convinced that Benjamin's philosophy holds important lessons for philosophy today at a time of continuing intellectual, cultural, and political crisis. In our view, Benjamin's reflections on the philosophical problems of subjectivity, experience, language, knowledge, truth, history and politics must be retranslated into the language of current struggles. The enduring fascination with Benjamin as a tragic hero of modernity has, for many years, caused both a 'bad' academisation of his work and a glib commercialization - even fetishisation - of his biography. Whereas the former consigns him to the formalised, institutional realms that he resisted (or that resisted him) during his lifetime, the latter tends to see in him little more than feuilletonistic fodder - a whimsical rebel of yesteryear. In each case what is forgotten is the imperative character of Benjamin's task. As Sami Khatib puts it in his contribution to the present volume, "instead of assimilating Benjamin to our times and reading our present into Benjamin's own historical present, our task is rather to read a Benjaminian text that was never written in the first place. Here, our historical distance to Benjamin's time appears as a connection through disconnection. It is only this truly historical discontinuity that we 'share' with Benjamin and the 'tradition of the oppressed'." ${ }^{59}$ With this in mind, we hope that the contributions collected in the present volume will prove to be illuminating.

\section{ENDNOTES}

1. Walter Benjamin, “The Task of the Translator", in: Selected Writings 1, 1913-1926, eds. Marcus Bullock \& Michael W. Jennings (Cambridge, MA: Belknap Press of Harvard University Press, 1996), p. 261.

2. Walter Benjamin, “The Life of Students", in: Selected Writings 1, 1913-1926, eds. Marcus Bullock \& Michael W. Jennings (Cambridge, MA: Belknap Press of Harvard University Press, 1996), p. 43. 
3. Walter Benjamin, “Two Poems by Friedrich Hölderlin”, in: Selected Writings 1, 1913-1926, eds. Marcus Bullock \& Michael W. Jennings (Cambridge, MA: Belknap Press of Harvard University Press, 1996), p. 18.

4. Walter Benjamin, "On Language as Such and on the Language of Man", in: Selected Writings 1, 1913-1926, eds. Marcus Bullock \& Michael W. Jennings (Cambridge, MA: Belknap Press of Harvard University Press, 1996), p. 70.

5. Walter Benjamin, "On the Program of the Coming Philosophy", in: Selected Writings 1, 1913-1926, eds. Marcus Bullock \& Michael W. Jennings (Cambridge, MA: Belknap Press of Harvard University Press, 1996), p. 100.

6. Walter Benjamin, "The Concept of Criticism in German Romanticism”, in: Selected Writings 1, 1913-1926, eds. Marcus Bullock \& Michael W. Jennings (Cambridge, MA: Belknap Press of Harvard University Press, 1996), p. 151.

7. Walter Benjamin, “Critique of Violence”, in: Selected Writings 1, 1913-1926, eds. Marcus Bullock \& Michael W. Jennings (Cambridge, MA: Belknap Press of Harvard University Press, 1996), p. 236.

8. Benjamin's most important sources for his formulation of the 'task' include Kant's concept of task, the Neo-Kantian conception of knowledge as an infinite task, Schlegel's dictum of the task of universal poetry, and the mystical, Jewish figure of tikkun olam - a motif from the Lurrianic Kabbalah that describes the task of restoring a shattered totality.

9. Cf. Walter Benjamin, "The Destructive Character", in: Selected Writings 2.2, 1931-1934, eds. Howard Eiland, Michael Jennings \& Gary Smith (Cambridge, MA: Belknap Press od Harvard University Press, 1999), pp. 541-542.

10. Walter Benjamin, "On the Concept of History", in: Selected Writings 4, 1938-1940, eds. Howard Eiland \& Michael W. Jennings (Cambridge, MA: Belknap Press of Harvard University Press, 2003), p. 392.

11. Ibid.

12. Ibid, p. 394.

13. Werner Hamacher, "Intensive Languages", trans. Ira Allen \& Steve Tester, MLN 127 (2012): p. 506.

14. Andrew Benjamin, Working with Walter Benjamin: Recovering a Political Philosophy (Edinburgh: Edinburgh University Press, 2013), p. 1.

15. Walter Benjamin, The Origin of German Tragic Drama, trans. John Osborne (London: Verso, 1998), p. 32 \& 36. [Emphasis added.]

16. The standard, English translation of the "Prologue" notoriously mis-renders Darstellung as 'representation'. To the extent that Benjamin is working with a Kantian vocabulary, however, Osborne's confusion of Darstellung ('presentation') and Vorstellung ('representation') obfuscates the way the text positions itself vis-à-vis the German philosophical tradition.

17. Cf. Howard Caygill, The Colour of Experience (London: Routledge, 1998).

18. Benjamin, "On the Program of the Coming Philosophy", p. 102

19. Benjamin, The Origin of German Tragic Drama, p.24.

20. Benjamin, "On the Program of the Coming Philosophy”, p. 103.

21. Ibid.

22. In the fragment "Theory of Knowledge" (1920-21) Benjamin writes: "Two things must be overcome: 1 . The false disjunction: knowledge is either in the consciousness of a knowing subject or else in the object (alternatively, identical with it). 2. The appearance of the knowing man (for example, Leibniz, Kant)." (Walter Benjamin, "Theory of Knowledge", in: Selected Writings 1, 1913-1926, eds. Marcus Bullock \& Michael W. Jennings [Cambridge, MA: Belknap Press of Harvard University Press, 1996], p. 276.)

23. Cf. Werner Hamacher, "Now: Walter Benjamin on Historical Time", in: Walter Benjamin and History, ed. Andrew Benjamin (London, New York: Continuum, 2005). 
24. Benjamin, The Origin of German Tragic Drama, p. 32. [Translation modified.] The German original reads as follows: "Ist Übung im beschreibenden Entwurfe der Ideenwelt, dergestalt, daß die empirische von selber in sie eingeht und in ihr sich lost, die Aufgabe des Philosophen, so gewinnt er die erhobne Mitte zwischen dem Forscher und dem Künstler. Der letztere entwirft ein Bildchen der Ideenwelt und eben darum, weil er es als Gleichnis entwirft, in jeder Gegenwart ein endgültiges. Der Forscher disponiert die Welt zu der Zerstreuung im Bereiche der Ideen, indem er sie von innen im Begriffe aufteilt. Ihn verbindet mit dem Philosophen Interesse am Verlöschen bloßer Empirie, den Künstler die Aufgabe der Darstellung." (Walter Benjamin, "Ursprung des Deutschen Trauerspiels", in: Gesammelte Schriften I.1, eds. Rolf Tiedemann \& Hermann Schweppenhäuser [Frankfurt/Main: Suhrkamp Verlag, 1974], p. 212.)

25. Ibid, p. 33. The German original reads as follows: "Die Phänomene gehen aber nicht integral in ihrem rohen empirischen Bestande, dem der Schein sich beimischt, sondern in ihren Elementen allein, gerettet, in das Reich der Ideen ein. Ihrer falschen Einheit entäußern sie sich, um aufgeteilt an der echten der Wahrheit teilzuhaben. In dieser Aufteilung unterstehen die Phänomene den Begriffen. Die sind es, welche an den Dingen die Lösung in die Elemente vollziehen." (Benjamin, "Ursprung des Deutschen Trauerspiels", p. 213-14.)

26. Ibid, p. 33. [Translation modified.]

27. Ibid, p. 34. The German original reads as follows: "Indem die Rettung der Phänomene vermittels der Ideen sich vollzieht, vollzieht sich die Darstellung der Ideen im Mittel der Empirie. Denn nicht an sich selbst, sondern einzig und allein in einer Zuordnung dinglicher Elemente im Begriff stellen die Ideen sich dar. Und zwar tun sie es als deren Konfiguration." (Benjamin, "Ursprung des Deutschen Trauerspiels", p.214.)

28. Ibid, p. [Translation modified.] 28. The German original reads as follows: "Darstellung ist der Inbegriff ihrer Methode. Methode ist Umweg. Darstellung als Umweg - das ist den der methodische Charakter des Traktats. Verzicht auf den unabgesetzten Lauf der Intentionen ist sein ersten Kennzeichen. Ausdauernd hebt das Denken stets von neuem an, umständlich geht es auf die Sache selbst zurück. Dies unablässige Atemholen ist die eigenste Daseinsform der Kontemplation. Denn indem sie den unterschiedlichen Sinnstufen bei der Betrachtung eines und desselben Gegenstandes folgt, empfängt sie den Antrieb ihres stets erneuten Einsetzens ebenso wie die Rechtfertigung ihrer intermittierenden Rhythmik." (Benjamin, “Ursprung des Deutschen Trauerspiels", p. 208.)

29. Ibid, p. 29. [Translation modified.] The German original reads as follows: "Erkenntnis ist ein Haben. Ihr Gegenstand selbst bestimmt sich dadurch, daß e rim Bewußtsein - und sei es transzendental - innegehabt werden muss. Ihm bleibt der Besitzcharakter. Diesem Besitztum ist Darstellung sekundär. Es existiert nicht bereits als ein Sich-Darstellendes.", (Benjamin, “Ursprung des Deutschen Trauerspiels", p. 209.)

30. Ibid, p. 30.

31. Cf. Andrew Benjamin \& Dimitris Vardoulakis (eds.), Sparks Will Fly: Benjamin and Heidegger (Albany: SUNY Press, 2015).

32. Ibid.

33. Ibid.

34. Benjamin, The Origin of German Tragic Drama, p. 34.

35. Ibid, p. 35.

36. Benjamin, "Theory of Knowledge", p. 276.

37. Ibid, p. 36. The German original reads as follows: "Sache des Philosophen ist es, den symbolischen Charakter des Wortes, in welchem die Idee zur Selbstverständigung kommt, die das Gegenteil aller nach außen gerichteten Mitteilung ist, durch Darstellung in seinen Primat wieder einzusetzen. Dies kann, da die Philosophie offenbarend zu reden sich nicht anmaßen darf, durch ein aufs Urvernehmen allererst zurückgehendes Erinnern einzig geschehen." (Benjamin, “Ursprung des Deutschen Trauerspiels", p.216-17.) 
38. Cf. Peter Fenves, Arresting Language: From Leibniz to Benjamin (Stanford: Stanford University Press, 2001).

39. Benjamin, "On Language as Such and on the Language of Man", p. 65.

40. Ibid, 64. [Translation modified.]

41. Ibid, p. 69. Cf. Winnfried Menninghaus, Walter Benjamins Theorie der Sprachmagie (Frankfurt/ Main: Suhrkamp, 1980).

42. Ibid, p. 65

43. Ibid, p. 68. Cf. Alexander García Düttmann, The Gift of Language: Memory and Promise in Adorno, Benjamin, Heidegger, and Rosenzweig (London: The Athlone Press, 2000).

44. Ibid, p. 69.

45. Samuel Weber, Benjamin's-abilities (Cambridge, MA: Harvard University Press, 2008), p. 9.

46. Peter Osborne \& Matthew Charles, "Walter Benjamin”, The Stanford Encyclopedia of Philosophy (Fall 2015 Edition), Edward N. Zalta (ed.), URL: https://plato.stanford.edu/archives/fall2015/ entries/benjamin.

47. Benjamin, The Origin of German Tragic Drama, p. 43. The German original reads as follows: "Das philosophische Gedankenreich entspinnt sich nicht in der ununterbrochenen Linienführung begrifflicher Deduktionen, sondern in einer Beschreibung der Ideenwelt. Ihre Durchführung setzt mit jeder Idee von neuem als einer ursprünglichen an." (Benjamin, "Ursprung des Deutschen Trauerspiels", p. 223.)

48. Ibid, p. 46. The German original reads as follows: "Vielmehr beginnt die Aufgabe des Forschers hier, der ein solches Faktum dann erst für gesichert zu halten hat, wenn seine innerste Struktur so wesenhaft erscheint, daß sie als einen Ursprung es verrät. Das Echte - jenes Ursprungsiegel in den Phnänomenen - ist Gegenstand der Entdeckung, einer Entdeckung, die in einzigartiger Weise sich mit dem Wiedererkennen verbindet." (Benjamin, "Ursprung des Deutschen Trauerspiels", p. 226-27.)

49. Ibid, p. 47.

50. Ibid, p. 48. [Translation modified.] The German original reads as follows: "Und so könnte denn wohl die reale Welt in dem Sinne Aufgabe sein, daß es gelte, derart tief in alles Wirkliche zu dringen, daß eine objective Interpretation der Welt sich drin erschlösse. Von der Aufgabe einer derartigen Versenkung aus betrachtet erscheint es nicht rätselhaft, daß der Denken der Monadologie der Begründer der Infinitesimalrechnung war. Die Idee ist Monade - das heist in Kürze: jede Idee enthält das Bild der Welt. Ihrer Darstellung ist zur Aufgabe nicht Geringeres gesetzt, als dieses Bild der Welt in seiner Verkürzung zu zeichnen.” (Benjamin, "Urspung des Deutschen Trauerspiels", p. 228)

51. Cf. Paula Schwebel, “Intensive Infinity: Walter Benjamin's Reception of Leibniz and its Sources”, in: MLN 127 (2012): pp. 589-610.

52. Schwebel, "Intensive Infinity”, p. 591.

53. Ibid.

54. Ibid.

55. Ibid.

56. Ibid, p. 601.

57. Ibid, p. 602.

58. Paul De Man, “Conclusions: Walter Benjamin's 'The Task of the Translator"', Yale French Studies 69 (1985), pp. 25-46.

59. Sami Khatib, "Where the Past Was There History Shall Be: Benjamin, Marx, and the 'Tradition of the Oppressed"', Anthropology \& Materialism [online], I (2017), URL: http://am.revues.org/789 
INDEX

Keywords: Benjamin Walter, Kant Immanuel, Leibnitz Gottfried Wilhelm, philosophy, subjectivity, philosophy of language, epistemology, experience, truth, theory of ideas, philosophy of history, origin, monadology, critical theory 